東北海区の海況変動の一例

\author{
福 岡 二 郎 \\ (中央気象台海洋課)
}

遊佳哪

（中央気象台海洋課）

\title{
An Example of the Variation of Oceanic Condition in the Adjacent Sea East of the Tohoku District.
}

By

\author{
J. FUKUOKA \\ (Central Meteorological Observatory, Tokyo) \\ T. YUSA \\ (Central Meteorological Observatory, Tokyo)
}

\begin{abstract}
Variation of surface water temperature can be regarded as a measure of variation of oceanic condition. For each $30^{\prime}$ square mesh of sea area east of Kinkazan, Miyagi Pref., surface water temperature was calculated by taking arithmetical mean of all the observed values. The rise or fall of the surface water temperature following summer will mean the growth of the Cold or the Warm Current in winter respectively. The rise and fall of water temperature of the sea from the surface to the depth of $100-200 \mathrm{~m}$, as obtained from the result of serial oceanographical observations, correspond to the rise and fall of the surface water temperature. Thus, it is considered that the variation of surface water temperature above mentioned is not caused by the variation of meteorological conditions, but is rather the variation of oceanic condition itself.
\end{abstract}

序 言 過去においては海沉の変動は比較的緩慢なものであると考えられた。この意味 で一隻の船で時日をかけて観測が行われた。しかし最近になり測器の進步と共て相当広範 曲の観測が短時日の間に行われるようになつた。(1) 我国では現在てれに類した一齊観測は 余り盛んに行れていない。しかし中央気象台では定点観測を実施してから每月二回，同じ 場所の海洋観測を行い得るようになつた。

こっでは東北海区の金華山沖の海洋観測資料より判朋した事実を報告する。

本 文 哣点観測船は $39^{\circ} \mathrm{N}, 153^{\circ} \mathrm{E}$ の地点で船をとぶめ終日観測を行い大体月 2 回の 交替を行う。乙の時の航路は殆ど一定している。しかも金華山沖では深層迄の海洋観測を 行つている。そてで緯度, 経度を 30'の桝目で区分し, その区域に含まれる表面水温を算 術平均して求めてみた。(第 1 図）乙れを年間にわたつて各地点の水温の变動を示した例が第 2 図である。この資料からある地点の表面水温が比較的はつきり定つてくる。 
Fig. 1. Map showing the mean water temperature for each $30^{\prime}$ square mesh. Observed Dec. 21 26, 1950.

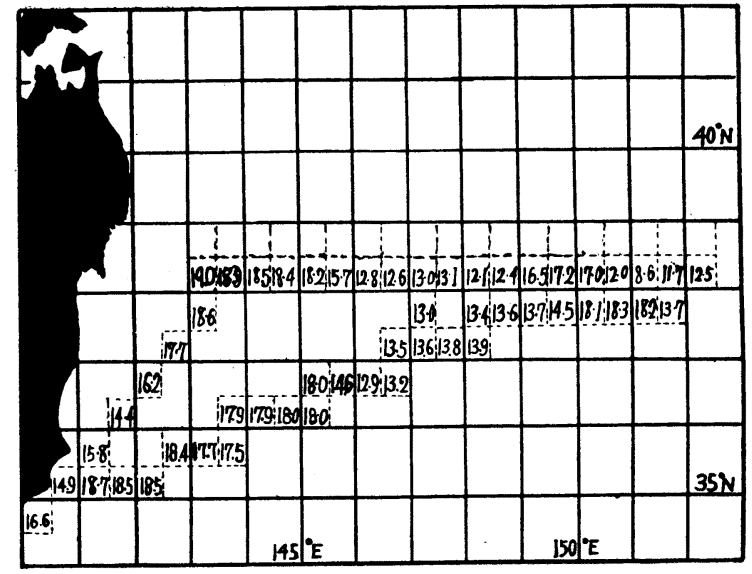

今ての資料より次のように考えてみた。

例えば昭和25年の冬季には冬になるに従つて水温が急昇する場合があり, 又26年の春夏 季には夏に近づくにつれて水温が著しく降る。(第 2 図參照)

Fig. 2. Variation of water temperature. (East off Kinkazan) - Water temperature at $38^{\circ} \mathrm{N}, 143^{\circ} \mathrm{E}$
- Water temperature at $38^{\circ} \mathrm{N}, 147^{\circ} \mathrm{E}$

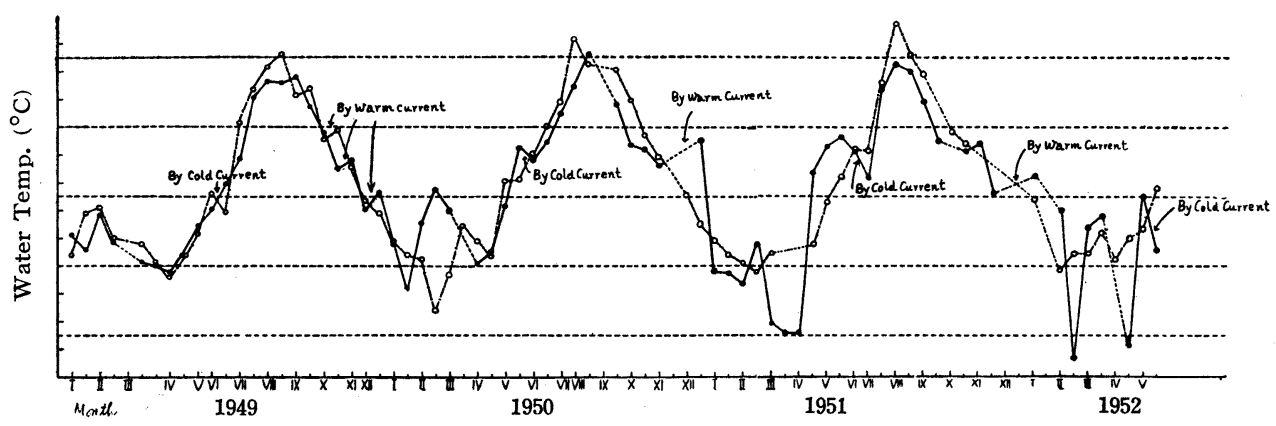

ての場合前者は冬季に著しい暖流系水の発達が, 後者では寒流系水の発達があつたよら 几考え弓る。その他気象の変化に応じての水温の上昇, 下降もあつたと考えてよん。 そてで次に海洋観測資料を調べてみた。

昭和 25 年 12 月 12 日之 12 月 24,25 日の観測を比較してみると第 3 図でも制るよう後者の 方が遙かて高温になつている。てのようを例は外にもみられると思らが一応金華山沖の表 面水温の変化丈からしらべると距岸 100 哩迄に昭和 24 年, 25年の冬に 2 回, 26年の冬に 3 回の昇温が認められる。 
Fig. 3. An example showing the rise of water temperature in winter.

Water Temp. $\left({ }^{\circ} \mathrm{C}\right)$

10 15

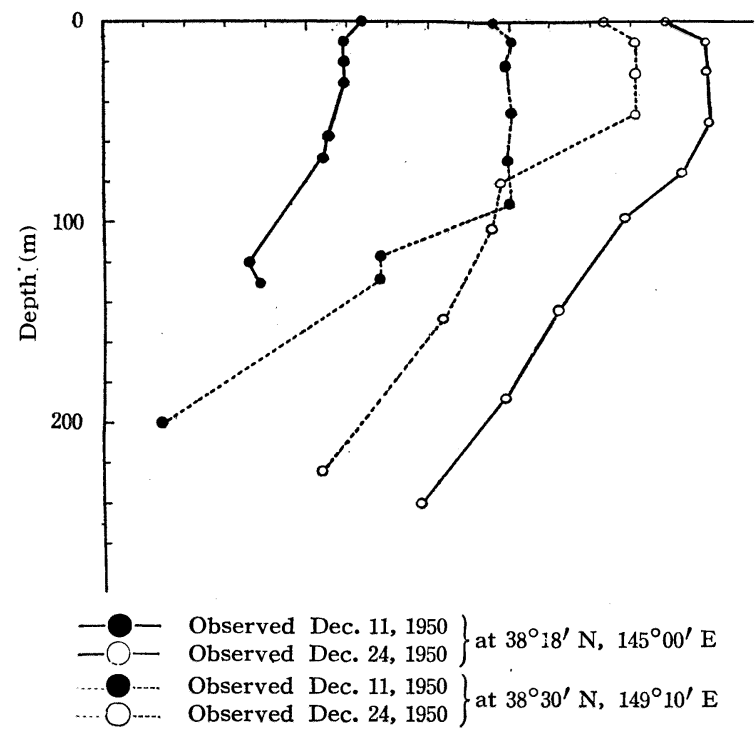

同様にして春から夏にかけての表面水温の変化を調べると夏になるにつれて水温の低下 する事実がある。即ち $38^{\circ} \mathrm{N}, 142^{\circ} \mathrm{E}$ の地点之。 $38^{\circ} \mathrm{N}, 145^{\circ} \mathrm{E}$ の地点の水溫を時期別に 書いてみると第1表のようになる。

- Table 1.

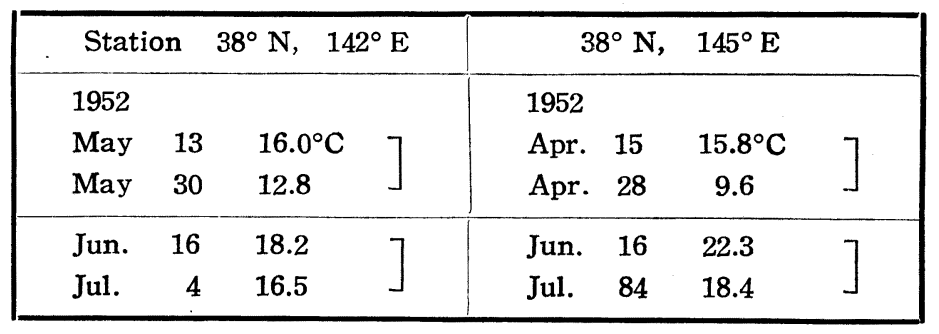

海洋観測の資料を調べると第 4 図のよう 5 月15日，6月17日，7月 5 日と日をおつて水溫 が低下している。

てのような深層迄の水溫の低下の例は昭和24年，25年では殆ど認められていない。 前にも述べたように気像の影響をしらべる必要はある訳だが，乙の水溫の変動が相当深 く迄及んでいる事から一応海自身の変化亡考えている。

次にこの現象を広範囲にわたり調查する為に，東北海域の水溫四をもと之し前旬差水溫 
4

日本海洋学会誌 第 8 卷第 1 号 (1952)

図をつくつてみた。第 5 図（a）には昭25和年冬季の前旬差水温を画いてあるが，てれをみ ると12月上，中，下旬之日を和つて高温水域が北上している事が伺われる。

Fig. 4. An example showing the fall of water temperature in spring and summer.

Water temp. $\left({ }^{\circ} \mathrm{C}\right)$

5

10

15

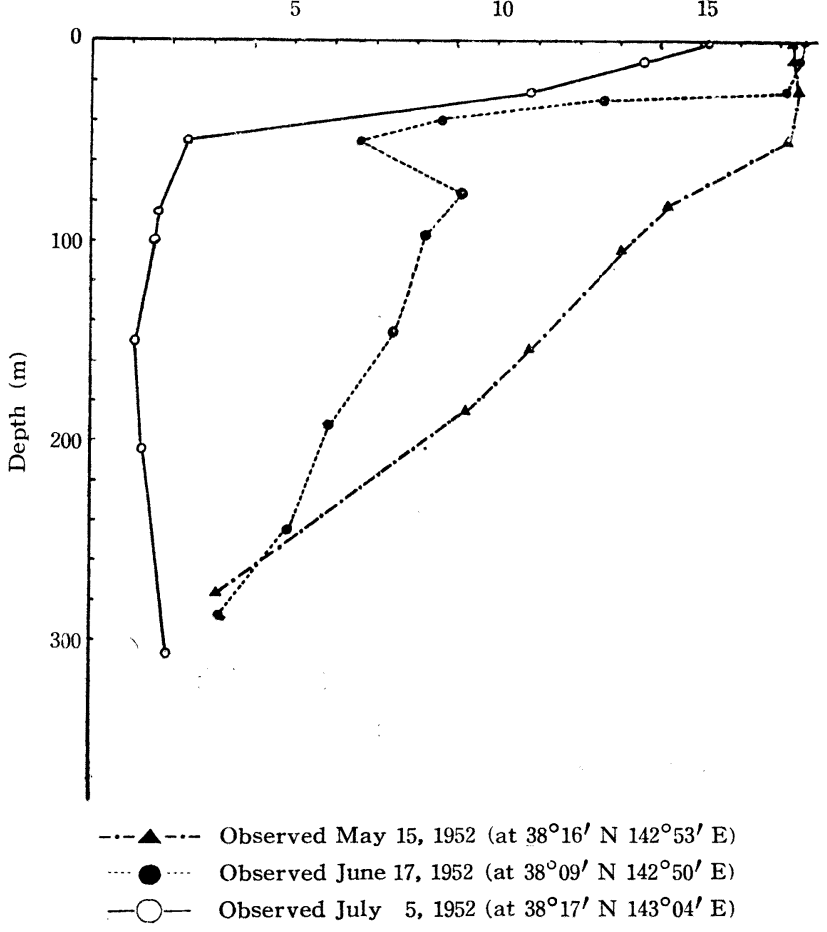

Fig. 5.(a) Difference of water temperature. (present decade-last decade)

First decade of Dec.

-third decade of Nov. 1950.

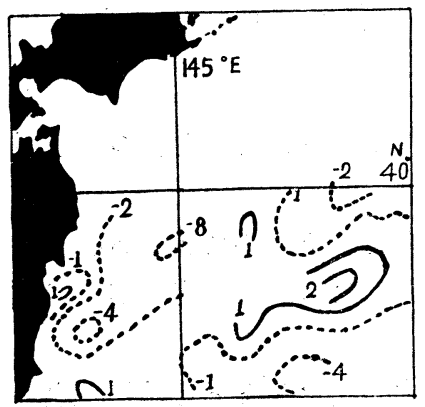

Second decade

— first decade of Dec. 1950.

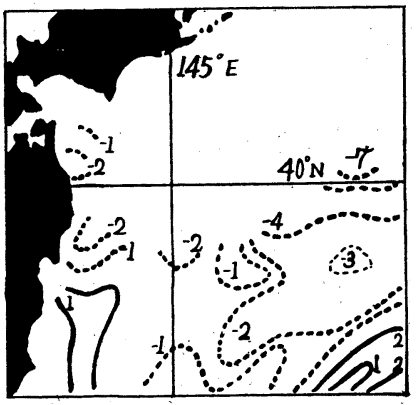

Third decade

- second decade of Dec. 1950.

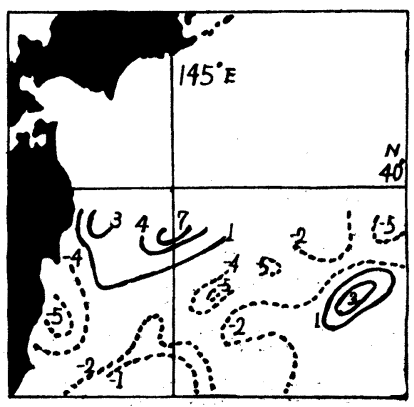

$(4)$ 
Fig. 5.(b) Difference of water temperature. (present decade-last decade)

First decade of June

— third decade of May, 1951.

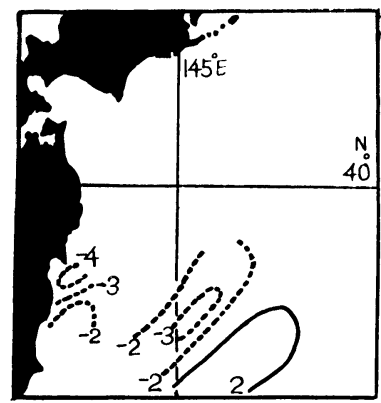

Second decade

- first decade of June, 1951.

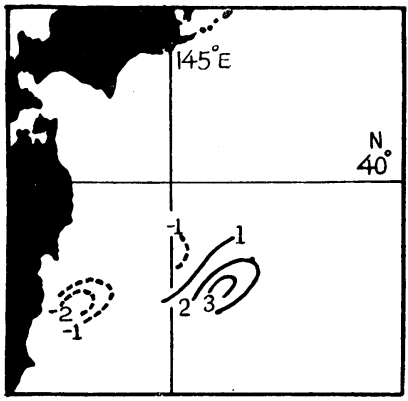

First decade of July

-third decade of June, 1951.

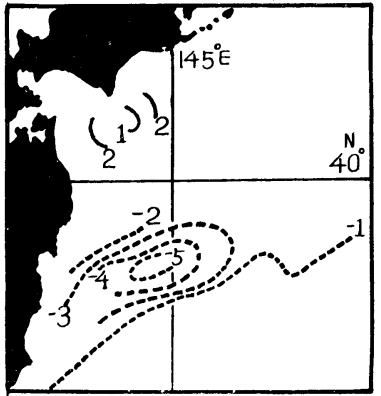

昭和26年 6 月，7月の同様を前旬差水温図を画いてみると第 5 図(b)のようになり，てれ から 6 月より 7 月上旬沉かけて金華山沖で相当低温な海水がみられたよらに考えられる。

最後に沿岸水温の前旬美を北海道の太平洋岸に就てしらべてみた。ての場合夏季の低温 水の発達の一つの目安として取上げた訳である。(第 6 図參照)てれをみると夏季には沿岸 水温が前句より低くなる事は殆どをい。唯 26 年 6 月中旬と著しい低温が認められる事は前 記の東北海区全域の前旬差水温図との関係を暗示するものであらう。

Fig. 6. Difference of water temperature. (present decade-last decade)

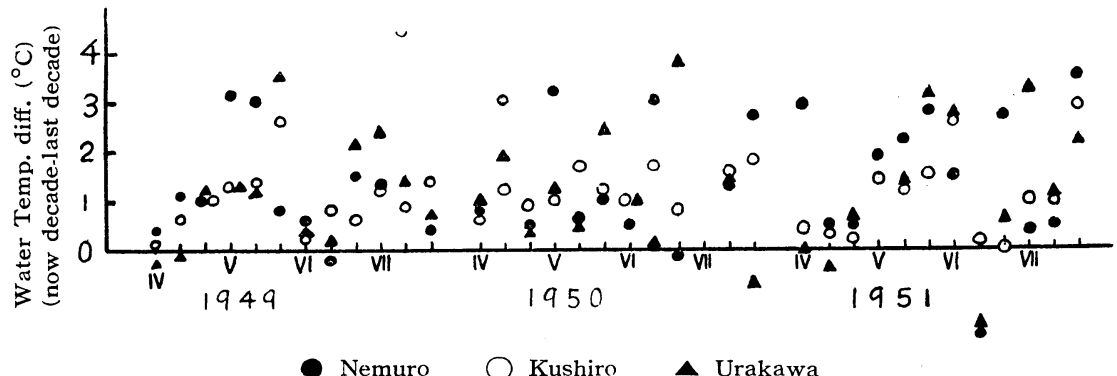

結 語 東北海区では以上の調查より冬及び初夏に水温の变動が激しい。特に比較的短 期間(1 ケ月以內) の海況の変動を知る必要がある。現在ての理由として極前線の移動によ るか，さもなくば全体の水塊の交替のような運動がおてつていると考えているが，今後の 調查も原因を追究に進めてゆくつもりである。

苶考文献

(1) F. C. Fuglister and L. V. Worthington: Some Results of a Multiple Ship Survey of the Gulf Stream. Tellus, Vol. 3 No. 1, Feb. 1951, p. $1 \sim 14$. 